\title{
The impact of human resource management practices on corporate performance: Empirical study in Jordanian commercial banks
}

\author{
Adnan M. Rawashdeh ${ }^{1 \star}$ and Izzat karim Al-Adwan ${ }^{2}$ \\ ${ }^{1}$ Department of Economic and Business, Girne American University, Cyprus. \\ ${ }^{2}$ Department Business Administration, Jinan University, Lebanon.
}

Accepted 24 September, 2012

\begin{abstract}
This study evaluates the impact of human resource management practices on corporate performance in Jordanian commercial banks. A total of 78 employees from the human resource departments of Jordanian commercial banks had responded to adapted questionnaire that measured three human resource practices and corporate performance. The results reflected a positive and statistically significant association of recruitment and selection, compensation and rewards with corporate performance, where training and development had showed a negative association with corporate performance.
\end{abstract}

Key words: Human resource management, corporate performance, commercial banks.

\section{INTRODUCTION}

Achieving competitive advantage and improving organizational performance relative to competitors are the main goals that business firms should strive to attain. Human resource management derived from the personnel management, considered as the effective management of employees, encourages the leadership that motivate people, draws on their talents, drives their participation in decision making, and takes in consideration their expectations and needs (Ehrlich, 1997).

Human resource management practices has the ability to create firms that are more intelligent, flexible, and competent than their rivals through the application of polices and practices that concentrate on recruiting, selecting, training skilled employees and directing their best efforts to cooperate within the resource bundle of the organization. This can potentially consolidate firm performance and create competitive advantage as a result of the historical sensitivity of human resources and the social complex of polices and practices that rivals may

*Corresponding author. E-mail: adnanrawa@yahoo.com. Tel: 00692796860622. not able to imitate or replicate their diversity and depth. Thus, in order to stimulate corporate performance, management is required to develop skilled and talented employees who are capable of performing their jobs successfully (Klein, 2004). Corporate performance is considered as the final result that firms seek to achieve positively (Ghosh and Mukherjee, 2006). Positive corporate performance can be created and sustained through the best exploit of human resources as an organizational intangible asset (Wright, 1998). Many scholars such as Sang (2005) investigated the influence of human resource management practices on firm performance and they found a positive relationship between those practices and firm performance.

Jordanian banking sector is considered as the most important service sector affecting Jordanian economy. It is growing very rapidly and continuously contributing to the gross domestic product that consisted of $80 \%$ services and $20 \%$ goods. The global economic crisis in 2008 had posed several threats on Jordanian banking industry, and to avoid these threats, banks management have declared a new policy which states a proactive approach on the development of human resources to the international standards. Aside from that, banks 
management have focused on achieving superior bank performance through the best use of talented human resources as a strategic asset where the global economic is down turning. Based on the aforementioned, this study emerged as an attempt to investigate the influence of human resource management practices on corporate performance in Jordanian commercial banks.

\section{LITERATURE REVIEW}

Lately, human resource management has become an important factor for achieving and sustaining competitive advantage. Also, its influence on corporate outcomes has become a central topic of studies established in the 1990s. One of these studies show that firms can create and sustain competitive position through management of unsubstitute, rare, valuable, and inimitable resources (Barney, 1991). Human resource management is considered as the most important resources of an organization, in that it selects the best candidates, and provides them with the right skills and abilities that can substantially influence the quality and quantity of firms' goods and services (Dessler, 2000). Human resource management practices can be defined as a set of organizational activities that aims at managing a pool of human capital and ensuring that this capital is employed towards the achievement of organizational objectives (Wright and Boswell, 2002). The adoption of certain bundles of human resource management practices has the ability to positively influence firm performance by creating powerful connections or to detract from performance when certain combinations of practices are inadvertently placed in the mix (Wagar and Rondeau, 2006).

Achieving better corporate performance requires successful effective and efficient exploit of firm resources and competencies in order to create and sustain competitive position locally and globally. It has been addressed in various ways and there are many aspects which may be adopted to explain corporate performance thoroughly, rather than an individual financial measure of profits which is hardly evaluated (Abdul, 2007). Divergent views exist to describe corporate performance based on different objectives of studies. This research describes corporate performance as operational performance. Several scholars proposed various dimensions to measure operational performance, such as Wendy (2008) who recommended service quality, operating efficiency, customer service quality, and meeting target times as operational performance measures. Khan (2010) suggested product cost, product quality, market share, performance relative to competitors, and organization's performance relative to industry average. Ahmad and Schroeder (2003) emphasized quality, cost reduction, flexibility, deliverability and commitment. Sang (2005) introduced quality, cost, product delivery, and production flexibility. Lee et al. (2010) proposed four dimensions: product quality, production cost, product delivery, and production flexibility.

Many contributors have recorded a positive relationship between human resource management practices and corporate performance. Khan (2010) conducted a research in Pakistan to investigate the effect of human resource management practices (recruitment and selection, training and development, performance appraisal, compensation and rewards, and employee relations) on organizational performance (product cost, product quality, market share, performance relative to competitors, and organization's performance relative to industry average) and he found a significant positive relationship between these practices and firm performance in 20 oil and gas companies. In a study in Pakistan, Boohene and Asuinura (2011) stressed that human resource management practices, particularly recruitment and selection, performance appraisal, remuneration, and training and development have positive effect on firm performance, the respondents were one hundred employees working in state-owned entity called graphic communication group in Ghana. Ahmad and Schroeder (2003) found a positive influence of human resource management practices (information sharing, extensive training, selective hiring, compensation and incentives, status differences, employment security, and decentralization and use of teams) on organizational performance as operational performance (quality, cost reduction, flexibility, deliverability and commitment). Sang (2005) found a positive influence of human resource management practices (namely, human resource planning, staffing, incentives, appraisal, training, team work, employee participation, status difference, employment security) on firm performance. The results derived from 160 respondents working in manufacturing firms in two countries (Cambodia and Taiwan) asserted a positive association between human resource management practices and operational performance (quality, cost, product delivery, and production flexibility). Boselie et al. (2005) analyzed 104 articles and found that the tope four human resource management practices investigated by different researchers are recruitment and selection, training and development, contingency and reward, and performance management, and had a positive influence on organizational performance. Proceeding further, many researchers found a positive relationship between individual human resource practices and firm performance, recruitment and selection (Delaney and Huselid, 1996; Terpstra and Rozell, 1993; Koch and McGrath, 1996), training and development (Huselid, 1995; Lee and Bruvold, 2003), compensation and rewards (Cunha et al., 2002; Batt, 2002).

From the earlier discussion, this quantitative study proposed three human resource management practices, namely recruitment and selection, training and development, and compensation and reward that are likely 
Table 1. Multiple linear regression analysis to test the relationship of human resource management practices with individually and corporate performance in Jordanian banking sector.

\begin{tabular}{lccccccccc}
\hline Variable & $\mathbf{r}$ & $\mathbf{R}^{2}$ & $\mathbf{f}$ & $\mathbf{S i g}(\mathbf{f})$ & $\mathbf{t}$ & $\mathbf{S i g}(\mathbf{t})$ & $\boldsymbol{\alpha}$ & $\boldsymbol{\beta}$ & Alternative decision \\
\hline Recruitment and selection & & & & & 2.09 & 0.040 & & 0.245 & Accept \\
Training and development & 0.879 & 0.773 & 84.10 & 0.000 & 1.79 & 0.076 & 0.798 & 0.184 & Reject \\
Compensation and rewards & & & & & 3.19 & 0.002 & & 0.423 & Accept \\
\hline
\end{tabular}

positively associated with corporate performance (product quality, product delivery, production cost, and production flexibility).

\section{Research hypotheses}

After reviewing literatures, this study provides the following hypotheses:

$\mathrm{H}_{1}$ : there is a significant relationship of recruitment and selection with corporate performance in Jordanian commercial banks

$\mathrm{H}_{2}$ : there is a significant relationship of training and development with corporate performance in Jordanian commercial banks.

$\mathrm{H}_{3}$ : there is a significant relationship of compensation and rewards with corporate performance in Jordanian commercial banks.

\section{RESEARCH METHODOLOGY}

\section{Population and sampling method}

The target population is the permanent workers of human resource departments, with a total of 119 employees working at 13 Jordanian commercial banks. The data sample collection strategy has surveyed a total of 119 employees who represent the whole population of the study.

\section{Data collection}

Questionnaire survey was used to collect primary data from the research sample. The questionnaire was in three segments. Segment A captured information about the respondents, such as information regarding, their organizational tenure, education, gender, and length of service in banking industry. Segment B captured information on bank's human resource management practices (recruitment and selection, compensation and rewards, and training and development). Segment $C$ tackled questions on corporate performance issues, respectively. In answering the questionnaire, the respondents were asked to indicate their responses to the questions on a five point likert scale ranging from 1 (strongly disagree) to 5 (strongly agree). The items used in the study were adapted from different studies (Wendy, 2008; Khan, 2010; Lee et al., 2010). The instrument was pilot tested using 25 employees from the population. The results of the pilot study reflected appropriate adequacy (Wu, 2005). The Cronbach's alpha of variables ranged from 0.85 to 0.92 , respectively. 119 questionnaires were dispatched to Jordanian commercial banks, a total of 84 filled questionnaires were received, and after investigation, a total of 6 questionnaires were found unfit for analyzation, so a total of 78 questionnaires have been used in analyzation which represent $66 \%$ response rate.

\section{RESULTS AND DISCUSSION}

\section{Reliability and validity of data}

The result of Cronbach's alpha for individual variable of recruitment and selection (0.92); training and development (0.89); compensation and reward (0.85); and organizational performance $(0.91)$ were found above acceptable level (Wu, 2005).

\section{Descriptive statistics}

The results of descriptive statistics indicated general agreement of the respondents to the different human resource management practices. The mean values ranged from highest (3.07) to lowest (2.20). The results for compensation and reward indicated highest conformity (Mean $=3.07$, Standard Deviation $=1.09$ ); training and development $($ Mean $=2.68$, Standard Deviation $=$ 1.14); recruitment and selection (Mean $=2.47$, Standard Deviation = 1.03); and corporate performance (Mean = 2.20 , Standard Deviation $=0.98$ ), respectively. The mean score and standard deviation reflected conformity of respondents' perception about these human resource management practices.

\section{Hypotheses testing}

Table 1 indicates the results of multiple linear regression analysis to test the relationship of human resource management practices (recruitment and selection, training and development, and compensation and rewards) with corporate performance in Jordanian commercial banks. The correlation coefficients (0.798) suggest a high positive relationship with corporate performance. The $f$ value $(84.10)$ indicate that there is a relationship with corporate performance as the value of the significance level $(0.000)$ related to $f$ value was less than 0.05 , suggesting the presence of the relationship. The value of $R^{2}$ shows how much the independent variable explain the variance of the dependent variable 
(corporate performance); upon this idea, human resource management practices (recruitment and selection, training and development, and compensation and rewards) explains $77.3 \%$ of the variance of corporate performance. On the other hand and as hypothesized, to investigate the relationship between these practices individually and in corporate performance, Table 1 showed the following results. For recruitment and selection, the $T$ value (2.09) reflects the importance of this element as the value (0.040) was less than 0.05 , indicating positive relationship with corporate performance. Thus, the test of hypothesis confirms the positive association of recruitment and selection with corporate performance and this result concur with the results of these studies (Khan, 2010; Delaney and Huselid, 1996; Terpstra and Rozell, 1993; Koch and McGrath, 1996). This positive significant relationship means that banks management have used a fair recruitment and selection criteria and the best applicant was posted to fill vacancy. These criteria are considered as a significant mechanism for stimulating firm performance. For training and development, the $T$ value (1.79) reflects the importance of this element as the value $(0.076)$ was more than 0.05 , indicating no relationship with corporate performance. Thus, the test of hypothesis did not support the results of prior studies (Huselid, 1995; Lee and Bruvold, 2003). This negative relationship means that banks management did not invest enough money in human resources through training and development programs, because they have applied cost reduction strategy in order to avoid threats posed by global crisis. Future researches required to investigate this area in order to support this result. For compensation and rewards, the $T$ value (3.19) reflects the importance of this element as the value (0.002) was less than 0.05 , indicating positive relationship with corporate performance. Thus, the test of hypothesis confirms the positive relationship of compensation and rewards and corporate performance, and this result concurs with the results of these studies (Khan, 2010; Cunha et al., 2002; Batt, 2002; Sang, 2005). This positive relationship shows that banks management has applied an effective compensation and reward mechanism which makes employees satisfied and committed to their job and organization which in turn result in reducing employee turnover. This balanced mechanism would attract professionals to join the banks and improve its performance.

\section{Conclusion}

The contribution of human resources and their management to the overall achievement of corporate performance in changing business environment is increasingly acknowledged. This study has evaluated the influence of human resource management practices on corporate performance in Jordanian commercial banks. Prior studies introduced positive effect of human resource management practices on corporate performance. This study empirically confirmed the findings of previous studies except the training and development. In a nutshell, this study has been conducted in Jordanian commercial banks and it concluded a positive relationship of human resource management practices (recruitment and selection, compensation and rewards) with corporate performance and negative association of training and development with corporate performance. Banks management should continue to ensure that all human resource management practices abide to banks policies and procedures, since the effective application of these practices will create and sustain superior bank performance. In addition, it would be valuable to ensure that investment in such practices will produce attraction and retention of talented employees.

\section{REFERENCES}

Abdul R (2007). HRM Sophistication and SME Performance: A Case of Ready Made Garment Manufactures and Exporters in Lahore. Pakistan. Unpublished Doctoral Thesis. And Twenty University. Pakistan.

Ahmad O, Schroeder R (2003).The Impact HRM Practices on Operational Performance: Recognizing Country and Industry Differences. J. Ops. Manag. 21:19-43.

Barney J (1991). Firm resources and sustained competitive advantage. J. Manag. 17(1):99-120.

Batt R (2002). Managing Customer Services: Human Resource Practices, Quit Rates, and Sales Growth. Acad. Manage. J. 45:587597.

Boohene R, Asuinura E (2011). The Effect of Human Resource Management Practices on Corporate Performance: A Study of Graphic Communications Group Limited. Int. Bus. Res. J. 4(1):266272

Boselie J, Dietz G, Boon C (2005). Commonalities and contradictions in HRM and Performance research. HRM J. 15(3):67-94.

Cunha R, Cunha M, Morgado A, Brewster C (2002). Market Impacts on Strategy, Human Resource Management Practices and Organizational Performance: Toward a European Model. Manag. Res. J. 1:79-91.

Delaney J, Huselid M (1996). The Impact of HRM Practices on Perceptions of Organizational Performance. Acad. Manag. J. 39(4):949-969.

Dessler G (2000). Human Resource Management. $8^{\text {th }}$ ed.$U p p e r$ Saddle River. New Jersey.

Ehrlich C (1997). Human Resource Management: A Changing Script for a Changing World. HRM J. 36(1):85-89.

Huselid M (1995). The Impact of HRM Practices on Turnover, Productivity, and Corporate Financial Performance. Acad. Manag. J. 38:635-672.

Ghosh S, Mukherjee S (2006). Measurement of Corporate Performance Through Balanced Scorecard: An Overview. Vidyasag. Univ. J. Comm. 11:60-70.

Khan M (2010). Effects of Human Resource Management Practices on Organizational Performance - An Empirical Study of Oil and Gas Industry in Pakistan. Eur. J. Econ. Financ. Admin. Sci. 24:157-175

Klein K (2004). Investigating the Use of Human Resource Management Best Practice in New Zealand Firms. Ota. Manage. Grad. Rev. J. 2:39-68.

Koch M, McGrath R (1996). Improving Labor Productivity: Human Resource Management Policies Do Matter. Strg. Manag. J. 17:335354.

Lee C, Bruvold N (2003). Creating Value for Employees: Investment in Employee Development. Int. J. HRM 14:981-1000.

Lee F, Lee T, Wua W (2010). The Relationship Between Human Resource Management Practices, Business strategy and Firm 
Performance: Evidence From Steel Industry in Taiwan. Int. J. HRM 21(9):1351-1372.

Sang C (2005). Relationship between HRM Practices and the Perception of Organizational Performance, Roles of Management Style, Social Capital, and Culture: Comparison between Manufacturing Firms in Cambodia and Taiwan. Unpublished Master Thesis. National Cheng Kung University. Tainan. Taiwan.

Terpstra D, Rozell E (1993). The Relationship of Staffing Practices to Organizational Level Measures of Performance. Person. Psychol. J. 46:27-48.

Wagar T, Rondeau K (2006). Retaining Employees in S\&M-Sized Firms: Examining the link with HRM. App. Manage. Entrepren. J. 11(2):3-16.
Wendy R (2008). Organizational Culture, HRM and Firm Performance: Examining Relationships Using the Competing Values Framework in Call Centers. Unpublished Doctorate Dissertation. Saint Mary's University. Halifax .Nova Scotia, Canada.

Wright P (1998). Introduction: Strategic Human Resource Management Research in the $21^{\text {st }}$ Century. HRM Rev. 8(3):187-152.

Wright P, Boswell W (2002). Desegregating HRM: A Review and Synthesis of Micro and Macro Human Resource Management Research. Manag. J. 28(3):247-276.

Wu W (2005). Business Research Methods. $2^{\text {nd }}$ ed. Taiwan: Hwa Tai Publishing. 